\title{
International
} Review

\section{of the}
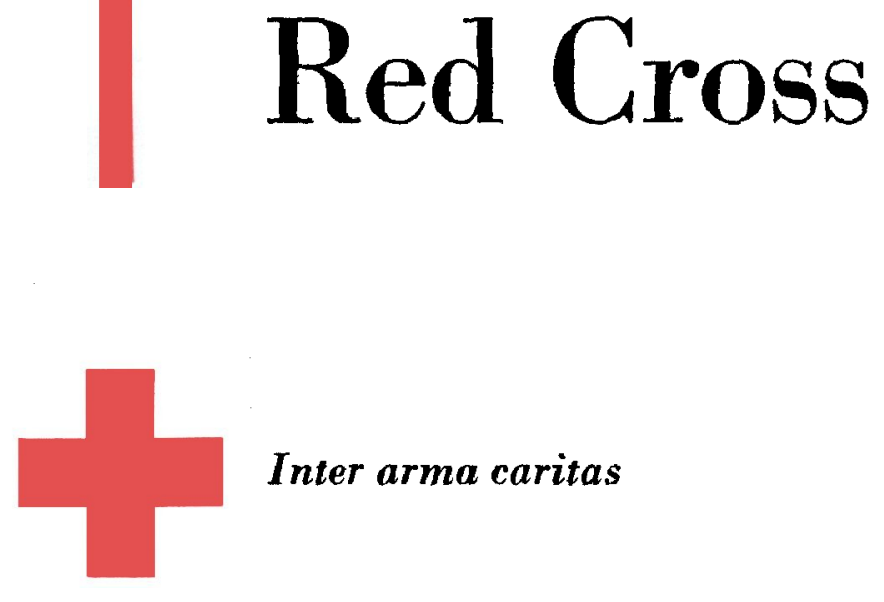

\section{Inter arma caritas}

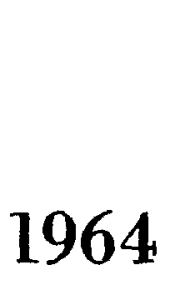

GENEVA

INTERNATIONAL COMMITTEE OF THE RED CROSS FOUNDED IN 1863 


\section{INTERNATIONAL COMMITTEE OF THE RED CROSS}

LEOPOLD BOISSIE R, Doctor of Laws, Honorary Professor at the University of Geneva, former Secretary-General to the Inter-Parliamentary Union, President (member since 1946)

JACQUES CHENEVIERE, Hon. Doctor of Literature, Honorary Vice-President (1919)

CARL J. BURCKHARDT, Doctor of Philosophy, former Swiss Minister to France (1933)

MARTIN BODMER, Hon, Doctor of Philosophy, Vice President (1940)

PAUL RUEGGER, former Swiss Minister to Italy and the United Kingdom, Member of the Permanent Court of Arbitration (1948)

RODOLFO OLGIATI, Hon. Doctor of Medicine, furmer Director of the Don Suisse (1949)

MARGUERITE VAN BERCHEM, former Head of Section, Central Prisoners of War Agency (1951)

FREDERIC SIORDET, Lawyer, Counsellor of the International Committee of the Red Cross from 1943 to 1951 (1951)

GUILlAUME BORDIER, Certificated Engineer E.P.F., M.B.A. Harvard, Banker (1955)

ADOLPHE FRANCESCHETTI, Doctor of Medicine, Professor of clinical ophthalmology at Geneva University (1958)

HANS BACHMANN, Doctor of Laws, Assistant Secretary-General to the International Committee of the Red Cross from 1944 to 1946, Vice-President (1958)

JACQUES FREYMOND, Doctor of Literature, Director of the Graduate Institute of International $S^{+}+1$ dies, Professor at the University of Geneva (1959)

DIETRICH SCHINDLER, Doctor of Laws (1961)

SAMUEL GONARD, former Colonel Commanding an Army Corps, former Professor at the Federal Polytechnical School (1961)

HANS MEULI, Doctor of Medicine, Brigade Colonel, former Director of the Swiss Army Medical Service (1961)

MARJORIE DUVILLARD, Directress of "Le Bon Secours " Nursing School (1961)

MAX PETITPIERRE, Doctor of Laws, former President of the Swiss Confederation (1961)

Honorary members

Miss LUCIE ODIER, Honorary Vice-President; Messrs. FRÉDÉRIC BARBEY and PAUL CARRY, Miss SUZANNE FERRIERE, Messrs. ÉDOUARD de HALLER, PAUL LOGOZ, ALFREDO VANNOTTI, ADOLF VISCHER.

Directorate: ROGER GALLOPIN, Doctor of Laws, Executive Director JEAN S. PICTET, Doctor of Laws, Director for General Affairs CLAUDE PILLOUD, Deputy Director for General Affairs 


\title{
I NTER NATIONAL REVIEW OF THE RED CROSS
}

\author{
FOURTH YEAR - No. 41 \\ $A U G U S T \cdot 1964$ \\ CONTENTS \\ CENTENARY
}

OF THE FIRST GENEVA CONVENTION

L. Boissier : Centenary of the first Geneva Convention . . . 393

In 1864 . . . . . . . . . . . . . . . . . . . . . . . 394

Four anniversaries . . . . . . . . . . . . . . . . . . 410

J. Pictet : The first Geneva Convention . . . . . . . . . 421

INTERNATIONAL COMMITTEE OF THE RED CROSS

Submission of Applications for the Florence Nightingale Medal (20th Award: May 12, 1965). . . . . . . . . . . 426

International Committee's action in the Yemen. . . . . . . . 428

Geneva Conventions . . . . . . . . . . . . . . . . . 432

International Committee's action in Cyprus. . . . . . . . . . 433

Newes Items . . . . . . . . . . . . . . . . . . . . . . . 435

†Léon Bossard, Delegate of the ICRC. . . . . . . . . . . 438

A special international status for civil defence personnel . . . . . 440 


\section{FRENCH EDITION OF THE REVIEW}

The French edition of this Review is issued every month under the title of Revue internationale de la Croix-Rouge. It is, in principle, identical with the English edition and may be obtained under the same conditions.

\section{SUPPLEMENTS TO THE REVIEW}

\section{SPANISH}

L. Boissier : Centésimo aniversario del primer Convenio de Ginebra. J. Pictet : El primer Convenio de Ginebra. - Un estatuto internacional especial para el personal de protección civil.

\section{GERMAN}

L. Boissier : Hundertster Jahrestag der Ersten Genfer Konvention. J. Pictet : Die Erste Genfer Konvention. - Internationales Sonderstatut für das Zivilschutzpersonal.

THE

\section{INTERNATIONAL REVIEW OF THE RED CROSS}

is problished each month by the International Committee of the Red Cross

7, Avenue de la Paix, Geneva, Switzerland Postal Cheque No. 12-1767

Annual subscription : Sw. fr. 25.-(\$6)

Single copies Sw. fr. $2.50(\$ 0.60)$

Editor: J.-G. LOSSIER 